\title{
Laboratory evaluation of some indigenous plant extracts as toxicants against red flour beetle, Tribolium castaneum Herbst
}

\author{
M. S. A. Mamun, M. Shahjahan ${ }^{1}$ and M. Ahmad ${ }^{1}$ \\ Entomology Division, Bangladesh Tea Research Institute, Srimangal, Moulvibazar, Bangladesh \\ ${ }^{1}$ Department of Entomology, Bangladesh Agricultural University, Mymensingh-2202, Bangladesh
}

\begin{abstract}
Experiments were carried out to evaluate the toxicity of six botanicals, Bazna (Zanthoxylum rhetsa), Ghora-neem (Melia sempervirens), Hijal (Barringtonia acutangula), Karanja (Pongamia pinnata), Mahogoni (Swietenia mahagoni) and Neem (Azadirachta indica) against red flour beetle, Tribolium castaneum Herbst. Leaf and seed extracts were prepared by using acetone, methanol and water as solvents. The results showed that extracts of all the six plants had direct toxic effect on red flour beetle. Among them, Neem seed extract showed the highest toxic effect (mortality, 52.50\%), whereas Hijal leaf extract possessed the lowest toxic effect (mortality, 22.24\%). Among the solvents, acetone extract showed more toxic effect than other extracts. Seed extracts of respective plants were slightly more toxic than leaf extract. The effectiveness of most of the plant extracts increased proportionally with the increase of doses and decreased with time.
\end{abstract}

Keywords: Plant extracts, Toxicity, Red flour beetle

\section{Introduction}

The red flour beetle is a common and most destructive pest of stored products and is cosmopolitan in distribution. Both the adults and grubs cause serious damage to all kinds of grains including flour and dried fruits. This pest generally found in granaries, mills, warehouse, and stored grains, feeding on rice (both husked and unhusked). Neither larvae nor adults could generally damage sound grains but they could feed on those grains only which had already been damaged by other pests. Currently different kinds of preventive and curative control measures are practiced to get protection from this pest. Among those, chemical pesticides have been used for a long time, but have serious drawbacks (Sharaby, 1988), such as direct toxicity to beneficial insects, fishes and human (Munakata, 1977; Pimental, 1981; Goodland et al., 1985), pesticide induced resistance (Brown, 1968; Georghiou and Taylor, 1977; Waiss et al., 1981), health hazard (Bhaduri et al., 1989) and increased environmental and social costs (Pimental et al. 1980). In many countries, efforts are being made to minimize the use of harmful insecticides through the use of indigenous plant products, implementation of IPM approaches, use of bio-degradable products (Khattach and Hameed, 1986) and applying insect growth regulators (Metcalf, 1975) to protect stored grains. In many areas of the world locally available plant materials are widely used to protect stored product against damage by insect infestation (Golob and Webley, 1980; Talukder et al., 1990). Botanical products are environmentally safe, less hazardous, economic and easily available. Botanicals like Bonkalmi, Bazna, Bishkatali, Datura, Durba, Eucalyptus, Ghora-neem, Hijal, Karanja, Mahogoni, Marigold, Neem, Nishinda, Pithraj, and many others may be grown by farmers with minimum expense and extracted by indigenous methods. These botanical materials can be used as an alternative to chemical pesticides. This will be very helpful in minimizing the undesirable side effects of synthetic pesticides. The present experiment was, therefore, undertaken to study the toxic effect of leaf and seed extracts of Bazna (Zanthoxylum rhetsa), Ghora-neem (Melia sempervirens), Hijal (Barringtonia acutangula), Karanja (Pongamia pinnata), Mahogoni (Swietenia mahagoni) and Neem (Azadirachta indica) in controlling red flour beetle.

\section{Materials and Methods}

The study was conducted in the laboratory of the Department of Entomology, Bangladesh Agricultural University (BAU), Mymensingh during the period from July 2004 to March 2005. The test insect species was collected from food godown of Mymensingh town and was maintained in the laboratory of the Department of Entomology, BAU, Mymensingh at 27 to $30^{\circ} \mathrm{C}$ temperature and $70-75 \%$ relative humidity. The insects were reared on sterilized wheat grains in rectangular jars $(9.5 \mathrm{~cm} \times 7.5 \mathrm{~cm} \times 20$ $\mathrm{cm})$. Each jar was set up with 20 pairs of adult insects and the newly emerged adults were utilized in the subsequent experiments of the present study. 


\section{Preparation of plant extracts}

Fresh leaves and seeds of Bazna, Ghora-Neem, Hijal, Karanja, Mahogoni and Neem were collected from the surroundings of BAU campus. Afterwards they were washed in running water. The plant materials were kept in shade for air-drying and then they were dried in the oven at $60^{\circ} \mathrm{C}$ to gain constant weight. Powdered samples were prepared by pulverizing the dried leaves and seeds with the help of a grinder. The ground samples were passed through a 25-mesh sieve to obtain fine and uniform dust. The dust was preserved in airtight condition in polythene bags till their use in extract preparation. Ten gram of sample of each category was taken in a $500 \mathrm{ml}$ beaker and mixed separately with $100 \mathrm{ml}$ of different solvents (acetone, methanol and distilled water). The mixture was stirred for 30 minutes by a magnetic stirrer (at $6000 \mathrm{rpm}$ ) and left to stand for next 24 hours. The mixture was then filtered through a fine cloth and again through filter paper (Whatman No.1). The filtrated materials were taken in a round bottom flask and condensed to $10 \mathrm{ml}$ by evaporation of solvent in a water bath maintained at $45^{\circ} \mathrm{C}, 55^{\circ} \mathrm{C}$ and $80^{\circ} \mathrm{C}$ temperature for acetone, methanol and water extracts, respectively. After the evaporation of solvent, the condensed extracts were preserved in tightly corked labeled bottles and stored in a refrigerator until their use for insect bioassay. Different concentrations of plant extracts were prepared by dissolving the stock solutions in the respective solvent prior to insect bioassay.

\section{Insect bioassays}

A laboratory test for direct toxicity by topical application method was conducted according to the method of Talukder and Howse (1993) with slight modification. Four different concentrations of each plant extracts $(5.0,7.5,10.0$ and $12.5 \%)$ were prepared with respective solvents. One microliter of prepared solution was applied to the dorsal surface of the thorax of each insect using a micropipette. Ten insects (five males \& five females) per replication were treated and each treatment was replicated thrice. In addition, the same number of insects were treated with solvent only for control. After treatment, the insects were transferred into $9 \mathrm{~cm}$ diameter petri dishes (10 insects/petri dish) containing wheat grains. Insect mortalities were recorded at 24, 48 and 72 hours after treatment (HAT). Original data were corrected by Abbott's (1987) formula: Percentage of corrected mortality = (Observed mortality-Control mortality/100-control mortality) x 100. The experimental data were statistically analysed by Completely Randomized Design (factorial CRD) using MSTAT statistical software in a microcomputer. The mean values adjusted by Duncan's Multiple Range Test (DMRT) (Duncan, 1951). LC 50 values were calculated by using probit analysis (Finney, 1971).

\section{Results and Discussion}

The effects of different leaf and seed extract of Bazna, Ghora-Neem, Hijal, Karanja, Mahogoni and Neem against red flour beetle, T. castaneum are presented in Tables 1-5.

Average mortality percentage of red flour beetle at 24,48 and 72 hours after treatment indicated that Neem seed extract possessed the highest (52.50\%) toxic effect, whereas Hijal leaf extract possessed the lowest $(22.24 \%)$ toxic effect (Table 1). The order of toxicity of the six plant extracts on red flour beetle, $T$. castaneum were: Neem>Karanja>Mahogoni>Ghora-Neem>Bazna>Hijal. The toxic effect of seed extracts were always higher than that of leaf extracts and were significantly different from each other (Table 2). Among the solvents, acetone extract was found more toxic $(40.39 \%)$ and it was significantly different from methanol $(34.79 \%)$ and water $(28.67 \%)$ extract (Table 3$)$. The maximum average mortality $(41.96 \%)$ was observed at the highest concentration $(12.5 \%)$ of plant extract and the mortality percentage was directly proportional to the level of concentration of plant extract (Table 4). 
Table 1. Mean mortality percentage of red flour beetle, $T$. castaneum treated with different plant part extracts by topical application method (Interaction of plant, plant part and time)

\begin{tabular}{|c|c|c|c|c|c|}
\hline \multirow{2}{*}{$\begin{array}{l}\text { Name of the } \\
\text { plants }\end{array}$} & \multirow{2}{*}{ Name of the plant parts } & \multicolumn{4}{|c|}{ Mortality percentage } \\
\hline & & $24 \mathrm{HAT}$ & $48 \mathrm{HAT}$ & $72 \mathrm{HAT}$ & Average \\
\hline \multirow[t]{2}{*}{ Bazna } & Leaf & 16.21 & 25.63 & 34.38 & $25.41^{\mathrm{h}}$ \\
\hline & Seed & 19.39 & 29.20 & 37.99 & $28.86^{\mathrm{g}}$ \\
\hline \multirow[t]{2}{*}{ Ghora-neem } & Leaf & 18.94 & 29.82 & 37.59 & $28.78^{\mathrm{g}}$ \\
\hline & Seed & 23.25 & 33.39 & 41.50 & $32.71^{\dagger}$ \\
\hline \multirow[t]{2}{*}{ Hijal } & Leaf & 13.84 & 22.05 & 30.84 & 22.24 \\
\hline & Seed & 16.94 & 24.52 & 33.33 & $24.93^{1}$ \\
\hline \multirow[t]{2}{*}{ Karanja } & Leaf & 28.25 & 40.57 & 47.67 & $38.83^{\mathrm{d}}$ \\
\hline & Seed & 31.73 & 43.90 & 52.18 & $42.60^{c}$ \\
\hline \multirow[t]{2}{*}{ Mahogoni } & Leaf & 22.73 & 34.30 & 41.91 & $32.98^{\dagger}$ \\
\hline & Seed & 26.79 & 38.50 & 46.75 & $37.34^{\mathrm{e}}$ \\
\hline \multirow[t]{2}{*}{ Neem } & Leaf & 36.12 & 50.47 & 58.07 & $48.22^{b}$ \\
\hline & Seed & 40.15 & 54.92 & 62.41 & $52.50^{\mathrm{a}}$ \\
\hline$S \bar{x}$ & & \multicolumn{3}{|c|}{0.1820} & 0.1051 \\
\hline Probability level & & \multicolumn{3}{|c|}{ NS } & 0.01 \\
\hline
\end{tabular}

HAT $=$ Hours after treatment, NS= Not significant

Within column values followed by different letter(s) are significantly different by DMRT.

Table 2. Effect of leaf and seed extracts on the mortality of red flour beetle, $T$. castaneum by topical application method (Interaction of plant part and time)

\begin{tabular}{|c|c|c|c|c|}
\hline \multirow{2}{*}{$\begin{array}{l}\text { Name of } \\
\text { the plant parts }\end{array}$} & \multicolumn{4}{|c|}{ Mortality percentage at different time intervals } \\
\hline & 24 HAT & 48 HAT & 72 HAT & Average \\
\hline Leaf & $22.68^{\dagger}$ & $33.81^{\mathrm{d}}$ & $41.75^{b}$ & $32.74^{b}$ \\
\hline Seed & $26.37^{\mathrm{e}}$ & $37.41^{\mathrm{C}}$ & $45.70^{\mathrm{a}}$ & $36.49^{a}$ \\
\hline$S \bar{x}$ & \multicolumn{3}{|c|}{0.0743} & 0.0429 \\
\hline Probability level & \multicolumn{3}{|c|}{0.01} & 0.01 \\
\hline
\end{tabular}

HAT= Hours after treatment

Within column and row values followed by different letter(s) are significantly different by DMRT.

Table 3. Effect of different solvents used in preparing different plant extracts on the mortality of red flour beetle, T. castaneum by topical application method (Interaction of solvent and time)

\begin{tabular}{|l|c|c|c|c|}
\hline \multirow{2}{*}{$\begin{array}{l}\text { Name of } \\
\text { the solvents }\end{array}$} & \multicolumn{3}{|c|}{ Mortality percentage at different time intervals } \\
\cline { 2 - 5 } & $24 \mathrm{HAT}$ & $48 \mathrm{HAT}$ & $72 \mathrm{HAT}$ & Average \\
\hline Acetone & $30.68^{\mathrm{f}}$ & $40.39^{\mathrm{C}}$ & $50.12^{\mathrm{a}}$ & $40.39^{\mathrm{a}}$ \\
\hline Methanol & $25.12^{\mathrm{h}}$ & $36.34^{\mathrm{e}}$ & $42.91^{\mathrm{b}}$ & $34.79^{\mathrm{b}}$ \\
\hline Water & $17.79^{\mathrm{b}}$ & $30.09^{\mathrm{g}}$ & $38.13^{\mathrm{d}}$ & $28.67^{\mathrm{C}}$ \\
\hline $\mathrm{S} \overline{\mathrm{X}}$ & \multicolumn{3}{|c|}{} & 0.0526 \\
\hline Probability level & 0.0910 & 0.01 \\
\hline
\end{tabular}

HAT = Hours after treatment

Within column and row values followed by different letter(s) are significantly different by DMRT.

Table 4. Effect of different doses of plant extracts on the mortality of red flour beetle, $T$. castaneum by topical application method (Interaction of dose and time)

\begin{tabular}{|c|c|c|c|c|}
\hline \multirow{2}{*}{ Doses (\%) } & \multicolumn{4}{|c|}{ Mortality percentage at different time intervals } \\
\hline & 24 HAT & $48 \mathrm{HAT}$ & 72 HAT & Average value \\
\hline 5.0 & $16.76^{\jmath}$ & $28.69^{9}$ & $37.54^{\mathrm{e}}$ & $27.66^{\mathrm{d}}$ \\
\hline 7.5 & $21.44^{\prime}$ & $33.23^{\dagger}$ & $41.37^{\mathrm{d}}$ & $32.01^{\mathrm{C}}$ \\
\hline 10.0 & $26.95^{n}$ & $37.75^{\mathrm{e}}$ & $45.81^{D}$ & $36.84^{\mathrm{b}}$ \\
\hline 12.5 & $32.96^{\dagger}$ & $42.76^{\mathrm{C}}$ & $50.17^{a}$ & $41.96^{\mathrm{a}}$ \\
\hline$S \bar{x}$ & \multicolumn{3}{|c|}{0.1051} & 0.0607 \\
\hline Probability level & \multicolumn{3}{|c|}{0.01} & 0.01 \\
\hline
\end{tabular}

HAT $=$ Hours after treatment

Within column and row values followed by different letter(s) are significantly different by DMRT. 


\section{Probit Analysis}

The results of the probit analysis for the estimation of $\mathrm{LC}_{50}$ values and their $95 \%$ fiducial limits and the slope of regression lines at 24, 48 and 72 HAT for the mortality of red flour beetle are presented in Table 5. The $\mathrm{LC}_{50}$ values of Bazna, Ghora-Neem, Hijal, Karanja, Mahogoni and Neem at 24 HAT indicated that Neem (11.35\%) was the most toxic and Hijal $(51.93 \%)$ was the least toxic. Neem also maintained its toxicity, when the LC $_{50}$ values were compared at $48(6.11 \%)$ and 72 HAT $(4.05 \%)$. Almost similar trend of results was also observed at 48 and 72 HAT. The Chi-square values of different plant extracts at different HAT were insignificant at $5 \%$ level of probability and did not show any heterogeneity of the mortality data.

Table 5. Relative toxicity (by probit analysis) of different plant extracts against red flour beetle at $24,48,72$ HAT

\begin{tabular}{|l|c|c|c|c|c|}
\hline $\begin{array}{l}\text { Name of the } \\
\text { extracts }\end{array}$ & $\begin{array}{c}\text { No. of the insects } \\
\text { used }\end{array}$ & $\begin{array}{c}\text { LC }_{50} \text { values } \\
(\%)\end{array}$ & $95 \%$ fiducial limits & $X^{2}$ values & Slope \pm SE \\
\hline \multicolumn{7}{|c|}{24 HAT } \\
\hline Bazna & 720 & 47.45 & $40.09-56.15$ & 0.55 & $0.97 \pm 0.05$ \\
\hline Ghora-neem & 720 & 38.34 & $33.15-44.34$ & 0.04 & $0.96 \pm 0.05$ \\
\hline Hijal & 720 & 51.93 & $43.46-62.05$ & 0.25 & $0.97 \pm 0.05$ \\
\hline Karanja & 720 & 16.85 & $14.57-19.49$ & 0.45 & $1.46 \pm 0.04$ \\
\hline Mahogoni & 720 & 28.83 & $20.71-40.14$ & 0.01 & $1.09 \pm 0.05$ \\
\hline Neem & 720 & 11.35 & $9.15-14.07$ & 0.58 & $1.79 \pm 0.04$ \\
\hline \multicolumn{5}{|c|}{48 HAT } \\
\hline Bazna & 720 & 20.94 & $15.52-28.24$ & 0.15 & $0.88 \pm 0.04$ \\
\hline Ghora-neem & 720 & 18.32 & $13.99-24.00$ & 0.20 & $0.85 \pm 0.04$ \\
\hline Hijal & 720 & 23.96 & $17.34-33.10$ & 0.34 & $0.93 \pm 0.04$ \\
\hline Karanja & 720 & 10.38 & $7.43-14.49$ & 0.28 & $1.02 \pm 0.04$ \\
\hline Mahogoni & 720 & 16.44 & $12.81-21.08$ & 0.12 & $0.81 \pm 0.04$ \\
\hline Neem & 720 & 6.11 & $4.33-8.64$ & 0.04 & $1.09 \pm 0.04$ \\
\hline \multicolumn{7}{|l|}{72 HAT } \\
\hline Bazna & 720 & 13.77 & $10.84-17.50$ & 0.06 & $0.67 \pm 0.04$ \\
\hline Ghora-neem & 720 & 12.09 & $9.66-15.14$ & 0.08 & $0.59 \pm 0.04$ \\
\hline Hijal & 720 & 16.85 & $12.22-23.22$ & 0.40 & $0.65 \pm 0.04$ \\
\hline Karanja & 720 & 6.43 & $4.27-9.69$ & 0.20 & $0.86 \pm 0.04$ \\
\hline Mahogoni & 720 & 9.34 & $6.01-14.49$ & 0.11 & $0.68 \pm 0.04$ \\
\hline Neem & 720 & 4.05 & $3.35-4.89$ & 0.38 & $1.10 \pm 0.04$ \\
\hline
\end{tabular}

HAT $=$ Hours after treatment

Values were based on two plant parts, three solvents, four concentrations, three replications of 10 insects each.

$x^{2}=$ Goodness of fit.

The tabulated value of $x^{2}$ is 5.99 (d.f. $=2$ at $5 \%$ level)

From the above probit results, it is clear that all the tested plants would be more or less effective for controlling red flour beetle but Neem will be the most effective one. The present study revealed the reduction of pest population by using leaf and seed extract of Neem and Karanja which is in line with the previous findings of Khaire et al. (1987), Singh et al. (1987), Durairaj et al. (1991) and Reddy et al. (1999).

It may be concluded the botanicals used had direct toxic effect. Among the tested plants Neem extracts showed the highest toxic effect and seed extract was more effective than leaf extract. Acetone extract showed the maximum toxicity followed by methanol and water extracts. Neem is available throughout the country and the farmers may use this plant in their storage structure for the management of stored grain pests. However, before releasing it as new technology further investigation is needed to confirm the result. 


\section{References}

Abbott, W.S. 1987. A method of computing the effectiveness of an insecticide. J. American Mosquito Cont. Assoc. 3: $302-303$.

Bhaduri, N., Gupta, D.P. and Ram, S. 1989. Effect of vegetable oils on the ovipositional behaviour of Callosobruchus chinensis Fab. pp. 81-84. In: Proc. 2nd Int. Symp. on Bruchids and Legumes (ISBL-2). Okayama, Japan.

Brown, A.W.A. 1968. Insecticide resistance comes of age. Bull. Entomol. Soc. America. 14(1): 3-9.

Duncan, D.B. 1951. A significance test for differences between ranked treatments in an analysis of variance. Virginia. J. Sci. 2(9): 171-189.

Durairaj, C., Ramaraju, K. and Sundarababu, P.C. 1991. Effect of plant derivatives on feeding and mortality of grapevine flea beetle, Scelodonta strigicollis L. Madras Agril. J. 78(1-4): 14-16.

Finney, D.J. 1971. Statistical method in biological assay (Second edition). Charles Griffin \& Co. London. 668 p.

Georghiou, G.P. and Taylor. C.E. 1977. Pesticide resistance as an evolutionary phenomenon. In: Proc. $14^{\text {th }}$ Int. Cong. Entomol. 759 p.

Golob, P. and Webley, D.J. 1980. The use of plants and minerals as traditional protectants of stored products. Rep. Trop. Prod. Inst. $32 \mathrm{p}$.

Goodland, R., Watson, C. and Ledec, G. 1985. Biocides bring poisoning and pollution to $3^{\text {rd }}$ world. The Bangladesh Observer, $16^{\text {th }}$ and $17^{\text {th }}$ January, 1995. p.3.

Khaire, V.M., Kachare, B.V. and Patil, C.S. 1987. Efficacy of different vegetable oils as grain protectants against Pulse beetle, Callosobruchus chinensis L. in increasing storability of Pigeon pea. Current Res. Reporter. 3(2): 153-156.

Khattach, S.U. and Hameed, M. 1986. Control of pulse beetle, Callosobruchus chinensis L. by gamma radiation, irradiated as unmated adults. Bangladesh J. Zool. 14(2): 167-169.

Metcalf, R.L. 1975. Insecticides in pest management. pp. 235-273. In: R.L. Metcalf and W. Luckmann (eds.). Introduction to insect pest management. Willey-Inter. Sci. New York.

Munakata, K. 1977. Insect antifeedants of Spodoptera litura in plants. pp. 185-196. Hedin. P.A. Host plant resistance to pests. ACS symposium series no. 62. Amer. Chem. Soc. Washington.

Pimental, D. 1981. An overview of integrated pest management (Mimeograph). Department of Entomology, Section of Ecology and Systematic, Cornell University, Ithaca, N.Y. p. 52.

Pimental, D., Andow, D., Dyson-Hudson, D., Gallahan, D., Jacobson, S., Irish, M., Croop, S., Moss, A., Schreiner, I., Shepard, M., Thompson, T. and Vinzant, B. 1980. Environmental and social cost of pesticides. A preliminary assessment. Oikos. 34:125-140.

Reddy, M.U., Bharati, S.R. and Reddy, D.D.R. 1999. Efficacy of some vegetable oils as protectants against the pulse beetle, Callosobruchus chinensis in Green gram, Phaseolus aureus during storage. Indian J. Nutrition and Dietetics. 36(10): 436-442.

Sharaby, A. 1988. Evaluation of some Mytraceae plant leaves as protectants against the infestation by Sitophilus oryzae L. and Sitophilus granarius L. Insect Sci. Appl. 9: 465-468.

Singh, A.K., Khan, A.M., Jain, M.K., Chandel, B.S. and Pandey, U.K. 1987. Insecticidal properties of some oils against Rhizopertha dominica F. a pest of stored grains. J. Angew. Zool. 74(4): 411-416.

Talukder, F.A. and Howse, P.F. 1993. Deterrents and insecticidal effect of extracts of Pithraj, Aphanamixis polystachya (Meliaceae) against Tribolium castaneum in storage. J. Chem. Ecol. 19: 2463-2471

Talukder, F.A., Shahjahan, M. and Ahad, M.A. 1990. Screening of some local botanicals against rice weevil, Sitophilus oryzae. Bangladesh J. Agric. 15(4): 283-284.

Waiss, A.C. Jr., Chen, B.G., Elliger, D.L., Dryer, D.L., Binder, R.G. and Gueldner, R.C. 1981. Insect growth inhibitor in crop plants. ESA Bulletin. 27(3): 217-221. 